\title{
Ecological analysis of abandoned forest plantations of Kannavam in Kerala, India.
}

\author{
Abhilash ES¹, ARR Menon², N Sasidharan², P Sujanapal2, VB Sreekumar² and Hareesh ${ }^{3}$
}

${ }^{1}$ Assistant Professor, Department of Botany, Sree Narayana College, Nattika, Thrissur, Kerala.

${ }^{2}$ Scientist, Kerala Forest Research Institute, Peechi, Kerala.

${ }^{3}$ Research Fellow, Kerala Forest Research Institute, Peechi, Kerala.

\section{Original Article}

\section{Corresponding Author}

Dr.Abhilash ES

Assistant Professor, P.G. Department of Botany

Sree Narayana College

Nattika, Thrissur, India

Email:abhies@gmail.com

\section{Abstract}

Phytosociological studies revealed Tectona grandis alone constitutes $66 \%$ of total tree volume, largest density (189.78), Most Frequently distributed, Higher I.V.I (110.59) followed by Aporusa lindleyana, I.V.I (34.26) , density (91.83) etc. As in the case of regenerants dominant saplings are Olea dioica (IVI= 81.66), Ixora brachiata (IVI= 73.06.) etc., emerged as well as established Seedlings include Ixora brachiata (IVI= 102.1), Aporusa lindleyana (IVI= 27.62). The average Shannon's diversity value for Moist deciduous forests in India is 2.18 and here, in Kannavam forest plantations it becomes 2.13 , which is very similar to typical moist deciduous forest. The presence of high endemism and considerable number of Rare, Endangered and Threatened plants shows its conservational importance.

Key Words: Phytosociology, Biodiversity, Species Richness, Species diversity, Endemic.

\section{Introduction}

The tropical regions are endowed with a remarkably high level of biological diversity and habitat heterogeneity; so there are roughly twice as many species in tropical regions in comparison to temperate ones. The environmental impacts of transforming forests through mining, forestry activities, shifting cultivation, agricultural development, wildlife exploitation and major engineering works are manifold. Inevitably, they diminish the forests, and destroy the essential discharge and waste processing capacity of the drainage system. In India, as in many tropical regions of the world, forest degradation continues due to various factors such as, extension of cultivation, grazing, extraction of forest products, hydroelectric projects and commercial plantations. Because of these activities, in the Western Ghats, nearly 40 percent of the natural vegetation has disappeared during the last eight decades (Menon and Bava, 1997).

The rich and diverse vegetational wealth of India undoubtedly is due to its immensely varying climatic and geographical conditions with varied ecological habitats. Hence, it is essential to have a reasonably fair assessment of floral and faunal components of the biodiversity for optimum utilization of resources. A study has been conducted in Kannavam plantation to assess its biodiversity aspects.

The Kannavam plantation ( 64.02 ha), lies in between $11^{\circ} 32^{\prime}$ to $12^{\circ} 5^{\prime}$ North latitude and $74^{\circ} 62^{\prime}$ to $75^{\circ} 42^{\prime}$ East longitude of Northern part of Kerala. The land is slightly undulated in the upper terrain and almost plain in lower elevations. Altitude ranges from $100-250 \mathrm{~m}$ ( $\mathrm{msl}$ ) and soil is of deep black alluvium. The climate is tropical maritime and monsoon in character. The south west monsoon brings the greater part of the total rainfall.

The heaviest precipitation occurs between June and August. The annual rainfall varies from $250 \mathrm{~cm}$ to $350 \mathrm{~cm}$, spread over 120-130 rain days. The plantation work of selected timber yielding species like Xylia xylocarpa, Terminalia paniculata, Deleinia pentagyna etc. started in 1933 and continued up to 1949 . Since 1949 no routine plantation management activities were done, the area was in abandon condition and was drastically undergone successional process which in turn enhanced the establishment of natural moist deciduous forest with considerable number of Rare, Endangered and Threatened species (RET). A study was conducted for assessing the current status of vegetation, with reference to regeneration of indigenous trees.

\section{Material and Methods}

Four steps have to be considered in any sampling of vegetation viz: (a) segmentation of the vegetation cover or recognition of entities, (b) selection of samples in the 
recognized segments, (c) the decision of what size and shape the samples should take and (d) the decision of what to record once the samples or plants are established (MullerDombois and Ellenberg, 1974).

Quadrats of 0.1 ha were laid out for each forest type pertaining to trees. $10 \mathrm{~m} \times 10 \mathrm{~m}$ quadrats for assessing the regeneration status of the area.

Density, Basal area (BA), Abundance, Frequency and its relative values were determined according to Curtis and McIntosh (1951) and Phillips (1959). The Importance Value Index (IVI) was worked out (Curtis and Mc-Intosh, 1951).

The following indices were used for the present study to ascertain species richness, diversity and evenness of the permanent vegetation of the study area.

For species richness study the Margalef (R1) are used.

$$
R 1=\frac{S-1}{\log (n)}(\text { Margalef, 1958) }
$$

Species diversity of the tree species was determined as per Shannon and Wiener $\left(H^{\prime}\right)$ (1949).

$$
H^{\prime}=-\Sigma \frac{\mathrm{ni}}{\mathrm{N}} \log \frac{\mathrm{ni}}{\mathrm{N}}
$$

where $n i=$ total number of individual of species ' $i$ ', and $N=$ total number of individuals of all species in the area.

The concentrations of dominance (CD) values were measured by Simpson's Index (1949). Simpson's index as:

$$
C D=\sum_{i=1}^{S}(N 1 / N) 2
$$

where N1 and N were the same as for the Shannon's information equation.

\section{Results and Discussion:}

Quantitative evaluation by establishing statistically designed census quadrate sampling method revealed that nineteen tree species, were enumerated with Tectona grandis alone constitutes $66 \%$ of the total tree volume. The high density (189.78) and basal area (224714.27) was also observed for Tectona grandis. Aporusa lindleyana showed next largest I.V.I

\begin{tabular}{|c|c|c|c|c|}
\hline Species & Density & Frequency & BA & IVI \\
\hline Albizia procera & 6.12 & 33.33 & 4445.42 & 5.86 \\
\hline Alstonia scholaris & 3.06 & 33.33 & 1234.4 & 4.36 \\
\hline Aporusa lindleyana & 91.83 & 100 & 24975.21 & 34.26 \\
\hline Artocarpus hirsutus & 12.24 & 33.33 & 9008.88 & 8.31 \\
\hline Bridelia retusa & 3.06 & 33.33 & 235.32 & 4.07 \\
\hline Dalbergia latifolia & 9.18 & 33.33 & 1295.59 & 5.49 \\
\hline Ficus exasperata & 3.06 & 33.33 & 4529.17 & 5.33 \\
\hline Flacourtia montana & 15.3 & 33.33 & 5491.74 & 7.82 \\
\hline Ixora brachiata & 36.73 & 66.66 & 9247.75 & 16.25 \\
\hline Naringi crenulata & 21.43 & 66.66 & 4835.29 & 12.19 \\
\hline Olea dioica & 61.22 & 66.66 & 12291.4 & 21.56 \\
\hline Schleichera oleosa & 58.16 & 66.66 & 25257.73 & 24.82 \\
\hline Stereospermum collais & 3.06 & 33.33 & 317.36 & 4.09 \\
\hline Strychnos nux-vomica & 3.06 & 33.33 & 235.32 & 4.07 \\
\hline Swietania mahagoni & 3.06 & 33.33 & 2448.73 & 4.72 \\
\hline Tectona grandis & 189.78 & 100 & 224714.42 & 110.59 \\
\hline Terminalia bellirica & 3.06 & 33.33 & 612.18 & 4.18 \\
\hline T.paniculata & 27.55 & 100 & 7557.85 & 17.53 \\
\hline Vitex altissima & 3.06 & 33.33 & 1727.82 & 4.51 \\
\hline Total & & & 340461.59 & \\
\hline
\end{tabular}
of 34.26 which is highly proliferating species next after tectona. Schleichera oleosa (IVI 24.82), Olea dioica (IVI 21.56) are also showing their ecological dominance (Table.1).
Table-1 Phytosociological parmeters.

Two species showed maximum frequency of hundred ie. Tectona grandis and Terminalia paniculata which indicate that they are most frequently distributed species in the said area. Twenty nine endemic species were recorded from the area of which 13 are of tree species, 4 shrubs, 5 climbers and 7 herbs.

As in the case of regeneration of tree species, small trees like Ixora brachiata, Aporusa lindleyana and Ficus hispida are the dominants among other regenerates. The 
regeneration of timber yielding species are comparatively less. The average Shannon's diversity value for Moist deciduous forests in India is 2.18 and here, in Kannavam forest plantations it becomes 2.13 , which is very similar to typical moist deciduous forest. The higher value of Margaleffs species richness index (3.46) also reveals its biodiversity richness. Now the area has been declared as "conservation plots" by means of its species richness and further felling was banned based on the study report submitted to Kerala Government.

As in the case of regenerants dominant saplings are Olea dioica (IVI= 81.66) followed by Ixora brachiata (IVI= 73.06.), Aporusa lindleyana (IVI=42.78) etc. Maximum basal area was observed for Olea dioica (2448) followed by Aporusa lindleyana (1066.67). Among the saplings maximum density were shown by Ixora brachiata and Olea dioica with hundred. High frequency was also observed for these species (66.67). The maximum IVI values for Seedlings are Ixora brachiata (IVI=102.1) followed by Aporusa lindleyana (IVI= 27.62), Ficus hispida (21.46) etc (Table.2).

Table.2. Vegetation status saplings.

\begin{tabular}{|l|l|l|l|l|}
\hline Species & Density & Frequency & BA & IVI \\
\hline $\begin{array}{l}\text { Actinodaphne } \\
\text { malabarica }\end{array}$ & 33.33 & 33.33 & 384 & 24.84 \\
\hline Aporusa lindleyana & 66.67 & 33.33 & 1066.67 & 42.78 \\
\hline $\begin{array}{l}\text { Helictres isora } \\
\text { Ixora brachiata }\end{array}$ & 33.33 & 33.33 & 600 & 27.88 \\
\hline $\begin{array}{l}\text { Olea dioica } \\
\text { Pterocarpus }\end{array}$ & 100 & 66.67 & 1837 & 73.06 \\
\hline $\begin{array}{l}\text { marcupium } \\
\text { Taberna monata } \\
\text { heyniana }\end{array}$ & 33.33 & 33.33 & 322.67 & 23.98 \\
\hline
\end{tabular}

Margaleff's species richness value obtained for arboreal vegetation in this study is 3.46 which quite low compared to the pristine moist deciduous forests of Goodrical and New Amarambalam (Table.3). But surprisingly it is higher than the some regions belonging to Peppara. Richness Index value of tree species in Southern secondary moist deciduous forest in Goodrical R.F is 10.17 which is higher than New Amarambalam (8.82) by Jayakumar (2003) and Peppara (2.38-4.18) by Varghese (1997).

The calculated value of Shannon's diversity index is 2.13 which show high diversity of species in the Kannavam area, which higher than the natural forests like Aralam, Parambikulam, Andaman Islands etc (Table.3).
Table 3. Diversity indices.

\begin{tabular}{|l|c|c|c|}
\hline Indices & Trees & Saplings & Seedlings \\
\hline Margaleff's richness index & 3.46 & 2.41 & 3.82 \\
\hline Shannon's diversity Index & 2.13 & 1.82 & 2.09 \\
\hline Shannon's diversity Index- Peppara & 2.28 & - & - \\
\hline Shannon's diversity Index -Andaman & 1.47 & - & - \\
\hline
\end{tabular}

For moist deciduous forest, the following values were reported: Aralam - 1.96 [Menon, 1999]; Parambikulam - 1.9 (Shankar and Sanal Kumar, 1997); Chimmony wild life sanctuary - 1.89-2.37 (Suraj, 1997); Agasthyavanam Biological Park (Vargheese, 1997); Moist deciduous forest of Andaman Islands - 1.47 (Roy et.al.1992 b) and Moist deciduous forests of Peppara wild life sanctuary - 2.28 (Varghese, 1997). The seedlings also showed high diversity (2.09) and High species richness (3.82) (Table.3). This shows its conservational importance.

29 Endemic plants were obtained from the study area including the IUCN declared conservationally important plants like Actinodaphne malabarica - Rare

IUCN 2010, Blepharistemma serratum- Vulnerable-IUCN 2010, Hopea parviflora- Endagered IUCN2010, Miquelia dentata - Rare- IUCN 2010. Epiphytes in the study area include Smithsonia straminea, Cymbidium aloefolium, Acampe praemorsa etc are well represented. Climbers are also abundant in the area like Desmos lawii, Spatholobus parviflorus, Jasminum pubescence, Ichnocarpus fruitescence, Nervilia zeylanica etc.

Conclusion:

Phytosociological studies revealed Tectona grandis alone constitutes $66 \%$ of total tree volume, largest density (189.78), Most Frequently distributed, Higher I.V.I (110.59) followed by Aporusa lindleyana , I.V.I (34.26) , density (91.83) etc. As in the case of regenerants dominant saplings are Olea dioica (IVI= 81.66), Ixora brachiata (IVI= 73.06.) etc., emerged as well as established Seedlings include Ixora brachiata (IVI= 102.1), Aporusa lindleyana (IVI= 27.62). The Shannon's diversity value for Kannavam forest plantations is 2.13 , which is very close to several typical moist deciduous forests. The higher value of Margaleffs species richness index (3.46) also reveals its biodiversity richness. The presence of high endemism and considerable number of Rare, Endangered and Threatened plants shows its conservational importance. Based on the study report submitted to Government of Kerala, the area has been protected as a conservation plot.

\section{Acknowledgments:}

The authors are extremely thankful to Director, KFRI for the help rendered during the study and Kerala Forest Department for financial assistance. 
References:

Curtis, J. T. and R. Mc-Intosh. 1951. An upland forest communities in the prairie forest border region of Wisconsin. Zoology. 32: 476-496.

Jayakumar, R. 2003. Studies on the Angiosperm flora and its diversity in New Amarambalam Reserve Forest of the Nilgiri bioreserve, Western Ghats of India. Ph.D thesis, FRI Deemed University, Dehra Dun.596 p.

Margalef, D.R. 1958. Information theory in ecology. General Systems. 3:36-71.

Menon, S. and Bava, K. S. 1997. Applications of geographic information systems, remote sensing, and landscape ecology approach to biodiversity conservation in the Western Ghats. Current Science. 73 (2): 134-144.

Muller-Dombois, D. and H. E1lenberg.1974. Aims and Methods of vegetation Ecology. Wiely international edition, New York. 547 p.

Phillips, A. E. 1959. Methods of vegetation study. Hentry Hott and Co, USA. $107 \mathrm{p}$.

Sankar, S. and M.G. Sanalkumar. 1997. Ecological and Environmental assessment of Forest Cover of Kerala with special reference to soil, vegetation and wildlife. KFRI Extension Report No.17.Kerala Forest Research Institute, Peechi, Thrissur. $84 \mathrm{p}$.

Shannon, C. E. and W. Weiner. 1949. The mathematical theory of communications. Urbana University Illinois press. 117 p.

Suraj, M. A. 1997. Phytosociological and vegetaion mapping of Chimmony Wildlife Sanctuary (Kerala) using remote sensing techniques. Ph.D thesis. FRI Deemed University, Dehra Dun. 146 p.

Vargheese, A. O. 1997. Ecological studies of the forests of the Peppara Wildlife Sanctuary using remote sensing techniques. Ph.D thesis, Forest Research Institute, Dehradun. $279 \mathrm{p}$.

\begin{tabular}{|l|l|}
\hline \multicolumn{2}{|c|}{ Article Information } \\
\hline \multicolumn{2}{|c|}{ Article history } \\
\hline Received & 21 October 2012 \\
Received in revised form & 15 November 2012 \\
Accepted & 2 December 2012 \\
\hline
\end{tabular}

